\title{
Combined Effects of Pre-cooling, Application of Natural Extracts and Packaging on the Storage Quality of Apple (Malus domestica) cv. Royal Delicious
}

\author{
R.M.N.A. Wijewardane and S.P.S. Guleria ${ }^{1}$ \\ Institute of Postharvest Technology \\ Research and Development Centre, Jayanthi Mawatha \\ Anuradhapura, Sri Lanka
}

\begin{abstract}
During recent years, global concern for protection of the environment has led researchers to investigate the use of natural flora as one of the sources for crop protection. The present investigation was also directed to find out the natural and ecofriendly fruit coating, package and storage alternatives for the extension of the storage life of apple (Malus domestica) cv. 'Royal Delicious'. Surface coating of apple with 1, 1.5, 2\% neem oil (Azadirachta indica) and 10, 15, 20\% extracts of marigold flower (Tagetes erectus), along with pre-cooling were tested on the storage quality of the fruit. The fruits were analyzed for physicochemical and physiological characters such as loss in weight, fruit firmness, total soluble solids (TSS) content, titratable acidity (TA), $\mathrm{pH}$, content of reducing sugars, pectin, total anthocyanin and polygalacturonase $(P G)$ activity. They were also analyzed for fruit spoilage. The results revealed that, surface-coating of apple with 1.5- 2\% concentration of neem oil along with pre-cooling was the most effective in providing better physico-chemical umbrella, effectively lowering fruit softening and PG enzyme activity, and significantly lowering fruit spoilage during storage. Similarly, packaging of fruits with corrugated fiber board (CFB) boxes + paper mould trays, CFB + Polyethylene (PE) liners and shrink-wrapped tray packing during storage $\left(2 \pm 1^{\circ} \mathrm{C}\right.$ and $\left.85-90 \% \mathrm{RH}\right)$, showed that the surface-coating of apple with $2 \%$ neem oil together with shrink-wrapped tray packing provided better retention of storage life of fruit and the treatment effect on physico-chemical characteristics of fruits were significant.
\end{abstract}

\section{INTRODUCTION}

Apple is the most important temperate fruit crop of the north western Indian Himalayan region. Indian Himalayas cover an area of 53 million ha, which is approximately 14\% of the total geographical area. The commercial cultivation of apple is largely confined to the states of Jammu and Kashmir, Himachal Pradesh, and Uttrakhand, which together account for 99\% of the total production (Anon, 2005). A number of researchers have made attempts to enhance the storage life of the apple using different substances at the pre or postharvest stages. However, most of the synthetic chemicals used for crop protection are reported to pose a serious threat to human health and have residual effect, besides being costly, thus, leading to search for safer and more competitive alternatives. Kleeberg (1996) has reported that azadirachtin, which is an active compound in neem oil, strengthens the pectin molecule by eliminating the chances of methyl group removal from the $\alpha$-galactouronic acid residue of pectin thus, helping in lowering the breakdown of pectin during storage. Singh et al., (2000) studied the effect of $\mathrm{GA}_{3}$ and plant extract, castor oil and neem oil on storage behaviour of

1 Department of Postharvest Technology, Dr Y S Parmar University of Horticulture and Forestry, Nauni, Solan173230 , India 
mango (Mangifera indica) cv. Langra and reported that the treatment of neem oil (10\%) showed the minimum physiological weight loss when compared to other treatments and controls, wherein, the maximum physiological weight loss $(17.28 \%)$ was recorded on the $12^{\text {th }}$ day of storage. At the same time, Singh et al., (2003) also reported the effect of various plant extracts such as neem leaves, castor oil and neem oil on citrus fruits and identified neem leaf extract as the best in retaining most of the biochemical characteristics.

The genus Tagetes (Asteraceae) with 56 species includes the popular ornamental budding plants known as marigolds. The distinguishing feature of the genus Tagetes is the presence of conspicuous brown black glands, which contain highly odoriferous components. Deshmukh et al., (1992) have reported the beneficial effects of Tagetes erectus flower on various horticultural and agricultural crops, which are attributed primarily to the presence of an organic compound 'camacin' exhibiting anti-fungal and insecticidal effects.

The temperature of the produce is directly proportional to the deterioration by decay and senescence and consequently, to the potential storage life. Pre-cooling facilitates good temperature management for prevention of ripening and effectively delaying the set of senescence. Besides, growth of most disease organisms and their spread is greatly reduced at lower temperatures. Thus, maintenance of low product temperature is essential in reducing water loss and subsequent product shrivelling (Kaynas and Sivritepe, 1995).

Proper packaging of a produce can reduce not only the bruising but also moisture losses, recontamination with spoilage organisms, and pilferage. The rate of ripening and the subsequent deterioration in its quality depend on respiration and transpiration losses. These physiological processes can be slowed down by using polyethylene box liners, which has good moisture barrier properties that will help in creating modified atmosphere conditions (Kader et al., 1989). Ryall and Uota (1955) found that Yellow Newton apples stored for six months in sealed polyethylene box (150 gauge) liners at $4.4{ }^{\circ} \mathrm{C}$ retained green colour and firm texture, and developed less scald than fruits in check boxes without film liners.

The optimum storage temperature for most apple cultivars is -1 to $1{ }^{\circ} \mathrm{C}$. However, the cultivar Delicious has shown higher storage life at $-1{ }^{\circ} \mathrm{C}$ than at $0{ }^{\circ} \mathrm{C}$ (Chadha and Awasthi, 2005). However, the most convenient storage temperature for most apple cultivars is just above freezing temperature, which is -1 to $-0.5^{\circ} \mathrm{C}$.

The present investigation was conducted to determine the effect of pre-cooling, in combination with the natural plant extracts as a fruit coating, and different packaging materials to enhance the storage quality of apple cv. 'Royal Delicious'.

\section{MATERIALS AND METHODS}

\section{Preparation of solutions and treatment of fruits}

Treatment solutions were prepared from the extract of marigold flowers (Tagetus erectus) and neem oil at different concentrations on the percentage weight basis. The flower extract was prepared by drying of flowers under shade followed by grinding them to a powder form in an electric blender. Aqueous solution of marigold was prepared by soaking a known weight of the powdered material in an equal quantity of water and keeping it overnight. Guar gum $(2 \%)$ was added to make a coating solution. The solutions of neem oil were prepared by proper mixing of oil with distilled water, emulsifying with guar gum on a percentage weight basis ( $2 \mathrm{ml}$ oil per $100 \mathrm{ml}$ of distilled water with $2 \%$ guar gum). 


\section{Collection of fruits and the treatments}

Apple (Malus domestica) fruits of the var. 'Royal Delicious' were procured from a well maintained commercial orchard situated at an elevation of $1650 \mathrm{~m}$ amsl in the village Chiathla (Kotkhai) at the Shimla District of Himachal Pradesh, India. The total number of fruits for this experiment was divided into two sets. Before transportation, one set was subjected to pre-cooling for $30 \mathrm{~min}$. at $10{ }^{\circ} \mathrm{C}$ in orchard itself by using a low-pressure container. The container was specially designed by modifying the head of an autoclave of 20 L capacity, provided with a glass flat-bottom flask designed as a humidifier. The pressure was maintained at $500 \mathrm{mmHg}$. The other set of fruits was not pre-cooled. Fruits from both sets were subjected to postharvest treatments as stated below.

The pre-cooled and non pre-cooled fruits were dipped in 10\% $\left(\mathrm{T}_{1}\right), 15 \%\left(\mathrm{~T}_{2}\right)$ and $20 \%\left(\mathrm{~T}_{3}\right)$ marigold flower extracts (Tagestus erectus) and 1\% $\left(\mathrm{T}_{4}\right), 1.5 \%\left(\mathrm{~T}_{5}\right)$, and $2 \%\left(\mathrm{~T}_{6}\right)$ of neem oil (Azadirachta india)for $5 \mathrm{~min}$. Fruits without treatment was used as the control $\left(\mathrm{T}_{7}\right)$. Then the fruits were packed in 3 types of packages namely, shrink-wrapped tray packing $\left(\mathrm{P}_{1}\right)$, Paper mould tray + CFB carton $\left(\mathrm{P}_{2}\right)$, LDPE (150 gauge), and liner + CFB carton $\left(\mathrm{P}_{3}\right)$.

\section{Fruit storage}

Samples of the fruits from all the treatments were weighed using a top loading balance (OHAUS model ARA 520), stored at cold storage $\left(2 \pm 1^{\circ} \mathrm{C}\right.$ and $\left.85-90 \% \mathrm{RH}\right)$ and the physiological and physico-chemical characteristics of fruits were recorded at an interval of 30 to 150 days of storage. The same experiment was conducted during August - December 2006 and 2007 to evaluate the seasonal difference.

\section{Physical characteristics}

After each storage interval, the fruit samples were weighed on a top loading balance (OHAUS, model ARA 520) and losses in weight during storage were expressed as percentage of initial weight on each sample date. Fruit firmness was measured with Effigi Penetrometer (model FT 327), which recorded the pressure required to force a plunger of 11 $\mathrm{mm}$ diameter into flesh of fruit samples.

\section{Physico-chemical characteristics}

The total soluble solids (TSS) content in fruit juice was recorded using a hand refractometer (ATAGO, model: HR-5) by squeezing the juice with cotton wool on to the cleaned sensor and reading was reported as ${ }^{\circ} \mathrm{Brix}$. The $\mathrm{pH}$ of a known amount of fresh and homogenized fruit juice in a $100 \mathrm{ml}$ beaker was recorded with a digital $\mathrm{pH}$ meter (Thermoorion, model $230 \mathrm{~A}+$ ) after standardizing the $\mathrm{pH}$ meter with buffer solutions of $\mathrm{pH} 4$ and 7 (Ranganna, 1986). The titratable acidity was determined as per Horwitz (1980) method where a known weight of fruit sample was crushed and taken into $250 \mathrm{ml}$ volumetric flask and the volume was made up. After filtration, $10 \mathrm{ml}$ of filtrate was titrated against $0.1 \mathrm{~N} \mathrm{NaOH}$ using phenolphthalein as the indicator. The reducing sugar content was estimated by Lane and Eynon's volumetric method (Horwitz, 1980). The pectin content was determined by Carre and Hayne's methods as described by Ranganna (1986) and expressed as per cent calcium pectate. The polygalcturonase activity (PG) was determined by the method described by Mahadevan and Sridhar (1982) where the enzyme action mixture consisted of enzyme extract $(2 \mathrm{ml})$ prepared by crushing fruit flesh, $4 \mathrm{ml}$ of sodium polypectate substrate (dissolving $750 \mathrm{mg}$ of the sodium polypectate in $100 \mathrm{ml}$ of acetate buffer, $\mathrm{pH} \mathrm{5.2,} \mathrm{heated} \mathrm{to}$ $50-60{ }^{\circ} \mathrm{C}$ and placed in a blender for mixing), and $1 \mathrm{ml}$ of acetate buffer. Using Ostwaldtype viscometer the content was mixed by drawing air gently through the large arm of the viscometer and suction was applied through the small arm, and the initial efflux time of 
mixture was determined. After $16 \mathrm{hr}$, the efflux time of the mixture was measured again. The anthocyanin pigments of apple fruit skin were extracted with a solvent mixture of acidic ethyl alcohol (Ranganna, 1986) and the intensity of colour was measured through $535 \mathrm{~nm}$ wavelength in a spectrophotometer against the blank. Spoilage of fruits due to fungal rots was calculated by adding up the number of fruits spoiled on successive storage intervals and calculating their percentage on the basis of number of fruits stored initially.

\section{Statistical analysis}

The experiments were carried out in a completely randomized design (CRD) with three replicates. Each replicate consisted of 25 fruits. Means were separated using Least Significant Difference (LSD) (at $\alpha=0.05$ ).

\section{RESULTS AND DISCUSSION}

\section{Physiological weight loss}

Pre-cooled fruits exhibited relatively slower loss in weight on the corresponding dates as compared to those without pre-cooling (Table 1), showing a lower physiological weight loss of $3.9 \%$, both in 2006 and 2007 . This may be due to the slower loss of moisture from precooled commodities when higher relative humidity is maintained in the storage atmosphere. Such conditions can easily be achieved by lowering the temperature as the storage environment tends to be more saturated simply by reduction in temperature (Lurie and Ben 1990). The results of the present study revealed that coating of fruits with $2 \%$ neem oil $\left(\mathrm{T}_{6}\right)$ with shrink-wrapped tray packing had the minimum physiological weight loss of $3.4 \%$ in 2006, The lowest physiological weight loss recorded in 2007 (3.5\%) was from the treatment with pre-cooling followed by fruits coated with $1.5 \%$ neem oil. These results are possibly due to the reduction of both the rate of metabolism and prevention of water loss as reported by Bhardwaj and Sen (2003).

Table 1. Effect of pre-cooling, fruit coating and packaging on the physiological weight loss $(\%)$ of Royal delicious apples during storage at $2 \pm 1^{\circ} \mathrm{C}$ for 150 days

\begin{tabular}{|c|c|c|c|c|c|c|c|c|c|c|c|c|}
\hline \multicolumn{2}{|c|}{$\begin{array}{l}\text { Treatments } \\
\end{array}$} & \multicolumn{5}{|c|}{2006} & \multicolumn{6}{|c|}{2007} \\
\hline & \multicolumn{3}{|c|}{$\mathrm{C}_{1}$} & \multicolumn{3}{|c|}{$\mathrm{C}_{2}$} & \multicolumn{3}{|c|}{$\mathrm{C}_{1}$} & \multicolumn{3}{|c|}{$\mathrm{C}_{2}$} \\
\hline $\mathbf{P}$ & $\mathbf{P}_{1}$ & $\mathbf{P}_{2}$ & $\mathbf{P}_{3}$ & $\mathbf{P}_{1}$ & $\mathbf{P}_{2}$ & $\mathbf{P}_{3}$ & $\mathbf{P}_{1}$ & $\mathbf{P}_{2}$ & $\mathbf{P}_{3}$ & $\mathbf{P}_{1}$ & $\mathbf{P}_{2}$ & $\mathbf{P}_{3}$ \\
\hline$\overline{\mathrm{T}_{1}}$ & $3.9^{\mathrm{e}}$ & $4.3^{\mathrm{e}}$ & $4.0^{\mathrm{d}}$ & $3.9^{\mathrm{d}}$ & $4.4^{\mathrm{c}}$ & $4.1^{\mathrm{e}}$ & $3.9^{d}$ & $4.1^{\mathrm{d}}$ & $3.9^{\mathrm{c}}$ & $3.9^{\mathrm{d}}$ & $4.2^{\mathrm{d}}$ & $4.0^{\circ}$ \\
\hline $\mathrm{T}_{2}$ & $3.8^{\mathrm{d}}$ & $4.2^{\mathrm{d}}$ & $3.9^{\mathrm{c}}$ & $3.9^{\mathrm{d}}$ & $4.2^{\mathrm{b}}$ & $4.0^{\mathrm{d}}$ & $3.8^{\mathrm{c}}$ & $3.9^{\mathrm{b}}$ & $3.9^{\mathrm{c}}$ & $3.8^{\mathrm{c}}$ & $4.1^{\mathrm{c}}$ & $4.0^{\circ}$ \\
\hline $\mathrm{T}_{3}$ & $3.6^{\mathrm{c}}$ & $4.2^{\mathrm{d}}$ & $3.7^{\mathrm{b}}$ & $3.6^{\mathrm{b}}$ & $4.2^{\mathrm{b}}$ & $3.9^{\mathrm{c}}$ & $3.6^{\mathrm{b}}$ & $4.1^{\mathrm{d}}$ & $3.9^{c}$ & $3.7^{\mathrm{b}}$ & $4.1^{\mathrm{c}}$ & $4.0^{\mathrm{c}}$ \\
\hline $\mathrm{T}_{4}$ & $3.5^{\mathrm{b}}$ & $4.1^{\mathrm{c}}$ & $3.9^{\mathrm{c}}$ & $3.7^{\mathrm{c}}$ & $4.2^{\mathrm{b}}$ & $3.7^{\mathrm{a}}$ & $3.8^{\mathrm{c}}$ & $4.0^{\mathrm{c}}$ & $3.8^{\mathrm{b}}$ & $3.9^{\mathrm{d}}$ & $3.8^{\mathrm{a}}$ & $3.9^{\mathrm{b}}$ \\
\hline $\mathrm{T}_{5}$ & $3.5^{\mathrm{b}}$ & $3.8^{\mathrm{a}}$ & $3.7^{\mathrm{b}}$ & $3.6^{\mathrm{b}}$ & $4.0^{\mathrm{a}}$ & $3.7^{\mathrm{a}}$ & $3.5^{\mathrm{a}}$ & $3.9^{\mathrm{b}}$ & $3.8^{\mathrm{b}}$ & $3.7^{\mathrm{b}}$ & $3.9^{\mathrm{b}}$ & $3.8^{\mathrm{a}}$ \\
\hline $\mathrm{T}_{6}$ & $3.4^{\mathrm{a}}$ & $3.9^{\mathrm{b}}$ & $3.6^{\mathrm{a}}$ & $3.5^{\mathrm{a}}$ & $4.0^{\mathrm{a}}$ & $3.8^{\mathrm{b}}$ & $3.6^{\mathrm{b}}$ & $3.8^{\mathrm{e}}$ & $3.7^{\mathrm{a}}$ & $3.6^{\mathrm{a}}$ & $4.1^{\mathrm{c}}$ & $3.9^{\mathrm{b}}$ \\
\hline $\mathrm{T}_{7}$ & $4.6^{\mathrm{f}}$ & $4.6^{\mathrm{f}}$ & $4.6^{\mathrm{e}}$ & $4.8^{\mathrm{e}}$ & $4.8^{\mathrm{d}}$ & $4.8^{\mathrm{f}}$ & $4.8^{\mathrm{e}}$ & $4.7^{\mathrm{e}}$ & $4.3^{\mathrm{d}}$ & $4.7^{\mathrm{e}}$ & $4.7^{\mathrm{e}}$ & $4.6^{\mathrm{d}}$ \\
\hline Mean & & 3.9 & & & 4.0 & & & 3.9 & & & 4.0 & \\
\hline
\end{tabular}

Note: $\mathrm{C}_{1}$ - pre-cooled; $\mathrm{C}_{2}$ - without pre-cooling; $\left(\mathrm{P}_{1}\right)$ - shrink-wrapped tray packing, $\left(\mathrm{P}_{2}\right)$ - Paper mould tray $+\mathrm{CFB}$ carton, $\left(\mathrm{P}_{3}\right)-\mathrm{LDPE}\left(150\right.$ gauge) liner $+\mathrm{CFB}$ carton; marigold flower extract: $\mathrm{T}_{1}-10 \%, \mathrm{~T}_{2}-15 \%, \mathrm{~T}_{3}-20 \%$ neem oil; $\mathrm{T}_{4}-1 \%, \mathrm{~T}_{5}-1.5 \%, \mathrm{~T}_{6}-2 \%, \mathrm{~T}_{7}$ - control. Means with same letters were not significantly different within each column $(\mathrm{p}=0.05), \mathrm{n}=3$ 


\section{Fruit firmness}

The decline in fruit firmness $(\mathrm{N}))$ was significantly lower $(\mathrm{p}<0.05)$ in pre-cooled fruits with higher mean fruit firmness $(59.2 \mathrm{~N})$ and $(59.0 \mathrm{~N})$ in 2006 and 2007, respectively, whereas, fruits without pre-cooling recorded $(57.9 \mathrm{~N})$ in both seasons (Table 2). The treatment with $2 \%$ neem oil $\left(\mathrm{T}_{6}\right)$ coupled with shrink-wrapped tray packing was the most effective treatment in retaining fruit firmness $(67.3 \mathrm{~N})$ and $(66.4 \mathrm{~N})$ with respect to pre-cooled fruits in both seasons.

Table 2. Effect of pre-cooling, fruit coating and packaging on the fruit firmness (N) Royal delicious apples during storage at $2 \pm 1^{\circ} \mathrm{C}$ for 150 days

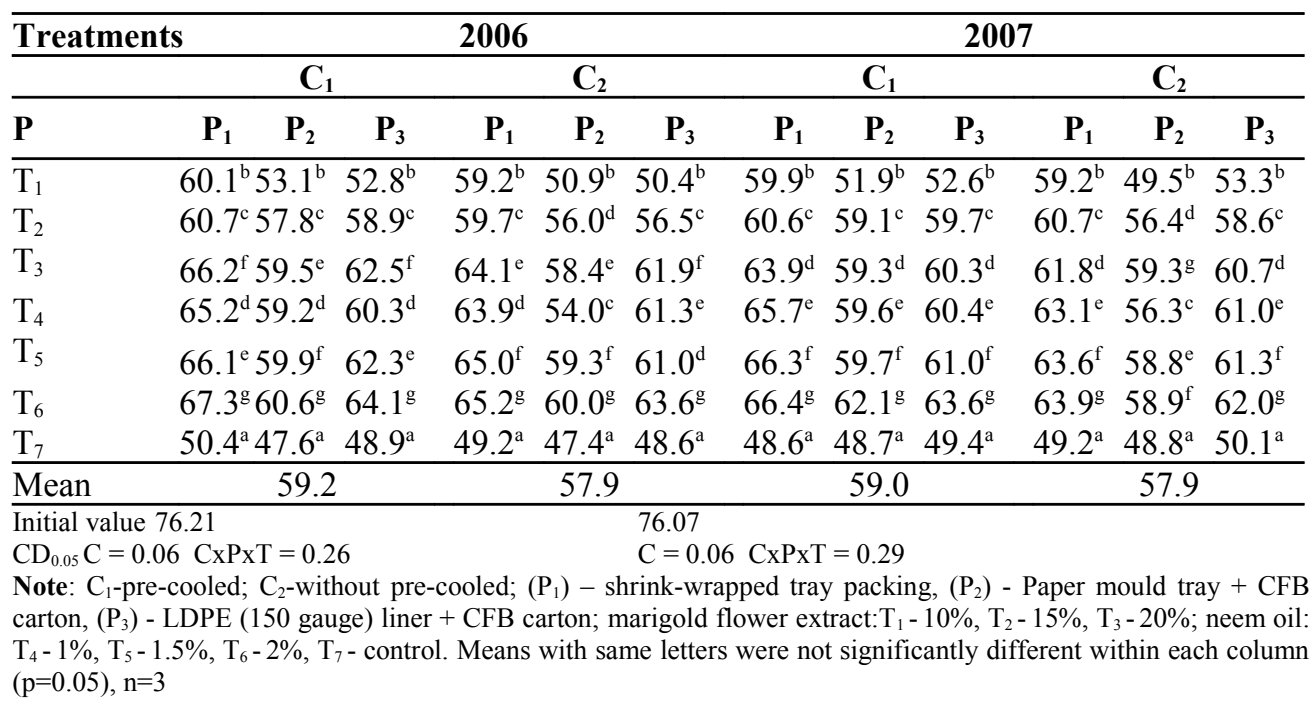

However, the possibility of achieving a modified atmosphere condition has been put forward as one of the advantages to be gained by the use of plastic films. This technique leads to the reduction of metabolic rates and prevention of water loss, which is further facilitated by the reduction in temperature (Singh and Chauhan, 1986). Similar observations were recorded by Anzueto and Rizvi (1985), where at $21^{\circ} \mathrm{C}$, the apple fruits packed in heat shrinkable polymer reached the maximum acceptable conditions at 6 weeks of storage against the shelf life extension of 3-4 weeks over non-packed controls.

\section{Titratable acidity and $\mathrm{pH}$}

A gradual decline in titratable acidity (Table 3) was observed with the advancement of storage period in all treatments. The $1.5 \%$ and $2 \%$ neem oil treatment $\left(\mathrm{T}_{6}\right)$ retained the maximum TA content $(0.3 \%)$ with the minimum fruit juice $\mathrm{pH}(3.7)$ in 2006 , whereas $1.5 \%$ neem oil $\left(\mathrm{T}_{5}\right)$ recorded the lowest value of $\mathrm{pH}(3.6)$ in year 2007 with respect to pre-cooled fruits packed in shrink wrapped tray package (Table 3 ). The lower level of titratable acidity content and higher $\mathrm{pH}$ was recorded in the control treatment $\left(\mathrm{T}_{7}\right)$. The faster rate of decline of acidity in fruits in the control treatment could be due to the faster metabolic reactions occurring within them. The application of different coating treatments may also slow down the metabolism of fruits as these have been reported to maintain higher $\mathrm{CO}_{2}$ and lower $\mathrm{O}_{2}$ levels inside the coated fruits (Kader et al., 1989). This explains the retention of higher acid 
levels and, consequently, lower $\mathrm{pH}$ values. Among the metabolic reactions, respiration is an important process, which may utilize organic acids as a substrate during the peak energy requirement of fruits, which usually coincides with ripening leading to a decrease in $\mathrm{pH}$ during prolonged storage (Sonkar and Ladaniya, 1999).

Table 3. Effect of pre-cooling, fruit coating and packaging on the titratable acidity (\% malic acid) and $\mathrm{pH}$ of Royal delicious apples during storage at $2 \pm 1{ }^{\circ} \mathrm{C} 150$ days.

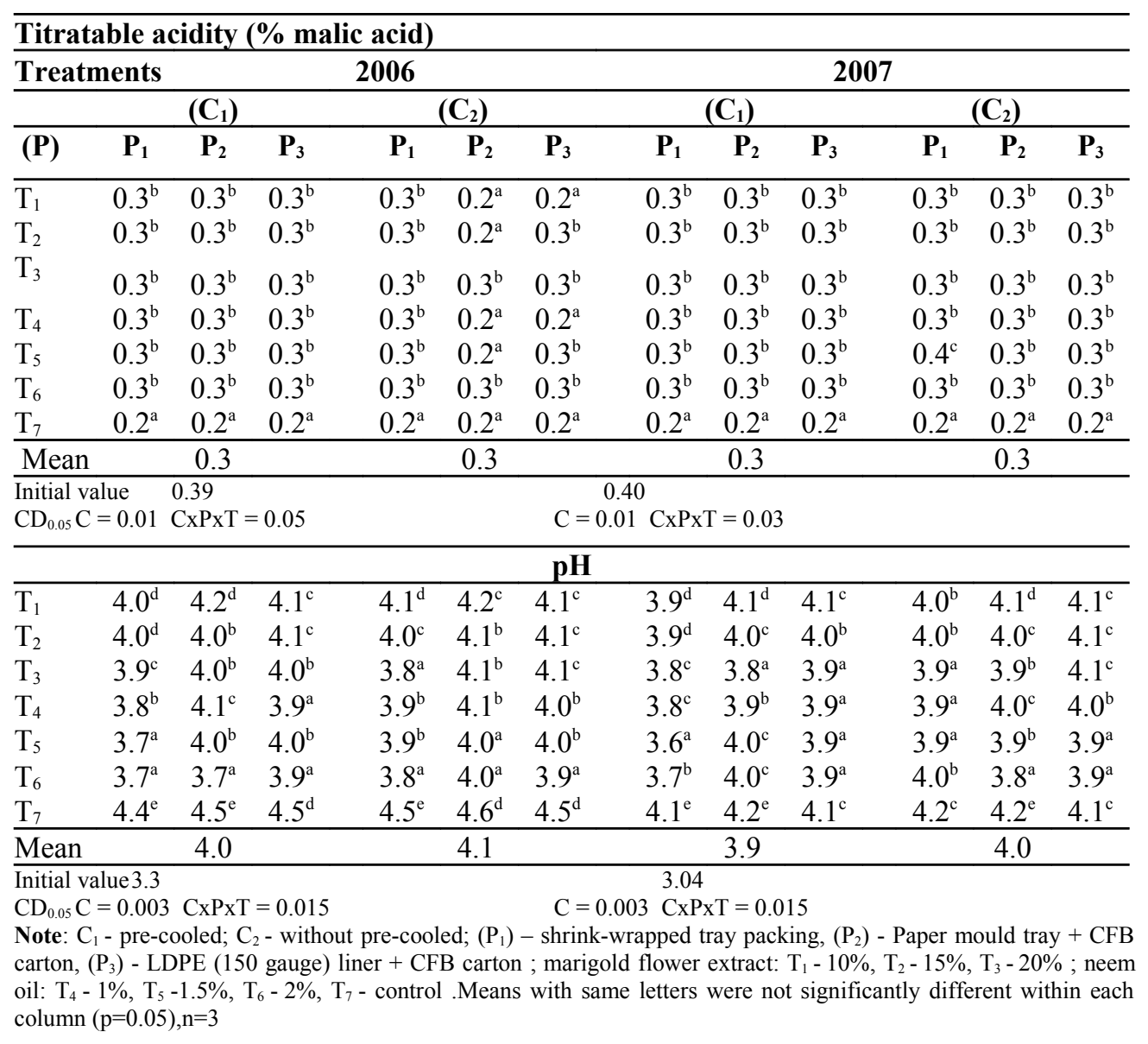

\section{Total soluble solids and reducing sugar contents}

The maximum total soluble solids (TSS) content of $13.0{ }^{\circ} \mathrm{Brix}-13.1{ }^{0} \mathrm{Brix}$ was recorded in response to coating with $1.5-2 \%$ neem oil with pre-cooled fruits, packed in shrink wrapped tray package in both seasons, and the minimum TSS content was recorded in the control treatment (Table 4). The increase in TSS and sugar content may be due to the hydrolysis of insoluble polysaccharides into simple sugars. Such changes are expected to be slower and more gradual when the metabolism of the commodity is slowed down by the application of various coating treatments, pre-cooling and under low temperature storage. 
Table 4. Effect of pre-cooling, fruit coating and packaging on the Total soluble solid content $\left({ }^{\circ} B\right)$ and Reducing sugar content $(\%)$ of Royal delicious apples during storage at $2 \pm 1{ }^{\circ} \mathrm{C}$ for 150 days

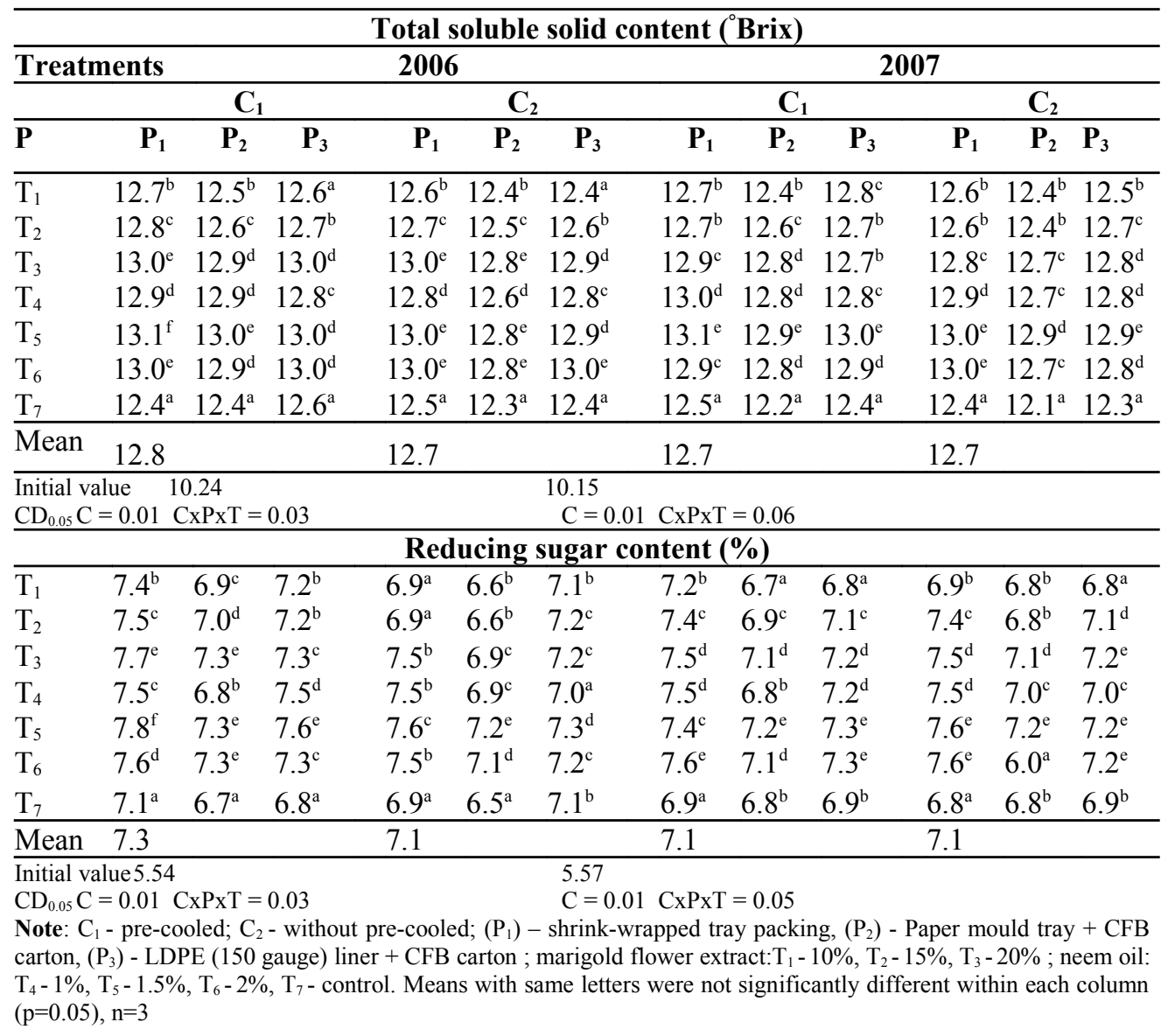

\section{Total anthocyanin content}

Pre-cooled fruits had a higher mean total anthocyanin content $(29 \mathrm{mg} / 100 \mathrm{~g}$ and 28.8 $\mathrm{mg} / 100 \mathrm{~g}$ ) when compared to that of the fruits without pre-cooling in the year 2006 and 2007, respectively (Table 5). The treatment with $1.5 \%$ neem oil showed the highest value of total anthocyanin content $(30.0 \mathrm{mg} / 100 \mathrm{~g})$ in pre-cooled, as well as in non-pre-cooled fruits in the year $2006(30.0 \mathrm{mg} / 100 \mathrm{~g})$ and $2007(29.8 \mathrm{mg} / 100 \mathrm{~g})$. A continuous decrease in the total anthocyanin content observed in all the treatments, whereas pre-cooling, coating and shrinkwrapped tray packing was effective for reduction in losses of pigment, may possibly be due to the delayed senescence of tissues which involve the degradation of these pigments (Table $5)$. 
Table 5. Effect of pre-cooling, fruit coating and packaging on the Total anthocyanin content (mg/100g) of Royal delicious apples during storage at $2 \pm 1{ }^{\circ} \mathrm{C}$ for 150 days

\begin{tabular}{|c|c|c|c|c|c|c|c|c|c|c|c|c|}
\hline \multirow{2}{*}{\multicolumn{2}{|c|}{ Treatments }} & \multicolumn{11}{|c|}{ Total anthocyanin content $(\mathrm{mg} / \mathbf{1 0 0 g})$} \\
\hline & & \multicolumn{5}{|c|}{2006} & \multicolumn{6}{|c|}{2007} \\
\hline & \multicolumn{3}{|c|}{$\mathbf{C}_{1}$} & \multicolumn{3}{|c|}{$\mathbf{C}_{2}$} & \multicolumn{3}{|c|}{$\mathbf{C}_{1}$} & \multicolumn{3}{|c|}{$\mathbf{C}_{2}$} \\
\hline $\mathbf{P}$ & $\mathbf{P}_{1}$ & $\mathbf{P}_{2}$ & $\mathbf{P}_{3}$ & $\mathbf{P}_{1}$ & $\mathbf{P}_{2}$ & $\mathbf{P}_{3}$ & $\mathbf{P}_{1}$ & $\mathbf{P}_{2}$ & $\mathbf{P}_{3}$ & $\mathbf{P}_{1}$ & $\mathbf{P}_{2}$ & $\mathbf{P}_{3}$ \\
\hline$\overline{\mathrm{T}_{1}}$ & $28.3^{\mathrm{b}}$ & $28.4^{\mathrm{b}}$ & $28.3^{\mathrm{b}}$ & $28.3^{\mathrm{b}}$ & $27.7^{\mathrm{b}}$ & $28.3^{\mathrm{b}}$ & $28.2^{\mathrm{a}}$ & $28.0^{\mathrm{b}}$ & $28.1^{\mathrm{a}}$ & $28.1^{\mathrm{b}}$ & $27.7^{\mathrm{b}}$ & $28.3^{\mathrm{c}}$ \\
\hline $\mathrm{T}_{2}$ & $28.5^{\mathrm{c}}$ & $28.4^{\mathrm{b}}$ & $28.5^{\mathrm{c}}$ & $28.6^{c}$ & $28.1^{\mathrm{c}}$ & $28.4^{\mathrm{e}}$ & $28.4^{\mathrm{c}}$ & $28.1^{\mathrm{c}}$ & $28.1^{\mathrm{a}}$ & $28.1^{\mathrm{b}}$ & $27.8^{\mathrm{c}}$ & $28.0^{\mathrm{a}}$ \\
\hline $\mathrm{T}_{3}$ & $29.4^{\mathrm{d}}$ & $29.4^{\mathrm{c}}$ & $29.4^{\mathrm{d}}$ & $29.5^{\mathrm{e}}$ & $28.3^{\mathrm{d}}$ & $28.6^{\mathrm{c}}$ & $29.2^{\mathrm{d}}$ & $28.9^{d}$ & $29.0^{\mathrm{b}}$ & $29.0^{c}$ & $28.7^{\mathrm{b}}$ & $28.9^{\mathrm{d}}$ \\
\hline $\mathrm{T}_{4}$ & $29.7^{\mathrm{f}}$ & $29.7^{\mathrm{e}}$ & $29.6^{\mathrm{e}}$ & $29.7^{\mathrm{f}}$ & $28.6^{\mathrm{e}}$ & $28.7^{\mathrm{d}}$ & $29.5^{\mathrm{e}}$ & $29.1^{\mathrm{e}}$ & $29.2^{\mathrm{c}}$ & $29.2^{\mathrm{d}}$ & $28.9^{d}$ & $29.1^{\mathrm{e}}$ \\
\hline $\mathrm{T}_{5}$ & $30.0^{\mathrm{g}}$ & $29.9^{f}$ & $30.0^{\mathrm{g}}$ & $30.0^{\mathrm{g}}$ & $29.9^{f}$ & $30.0^{\mathrm{g}}$ & $30.0^{\mathrm{f}}$ & $29.5^{\mathrm{g}}$ & $29.5^{\mathrm{e}}$ & $29.8^{\mathrm{f}}$ & $29.5^{\mathrm{f}}$ & $29.6^{\mathrm{g}}$ \\
\hline $\mathrm{T}_{6}$ & $29.6^{\mathrm{e}}$ & $29.5^{\mathrm{d}}$ & $29.7^{\mathrm{f}}$ & $29.8^{\mathrm{d}}$ & $29.3^{\mathrm{d}}$ & $29.4^{\mathrm{f}}$ & $29.5^{\mathrm{e}}$ & $29.2^{f}$ & $29.4^{\mathrm{d}}$ & $29.4^{\mathrm{e}}$ & $29.1^{\mathrm{e}}$ & $29.2^{\mathrm{f}}$ \\
\hline $\mathrm{T}_{7}$ & $27.4^{\mathrm{a}}$ & $27.5^{\mathrm{a}}$ & $27.4^{\mathrm{a}}$ & $27.5^{\mathrm{a}}$ & $27.4^{\mathrm{a}}$ & $27.2^{\mathrm{a}}$ & $28.3^{\mathrm{b}}$ & $27.9^{\mathrm{a}}$ & $28.1^{\mathrm{a}}$ & $28.0^{\mathrm{a}}$ & $27.6^{\mathrm{a}}$ & $28.1^{\mathrm{b}}$ \\
\hline \multicolumn{2}{|l|}{ Mean } & 29.0 & & & 28.7 & & & 28.8 & & & 28.7 & \\
\hline \multicolumn{13}{|c|}{$\begin{array}{l}\text { Note: } C_{1}-\text { pre-cooled; } \mathrm{C}_{2}-\text { without pre-cooled; }\left(\mathrm{P}_{1}\right) \text { - shrink-wrapped tray packing, }\left(\mathrm{P}_{2}\right)-\text { Paper mould tray }+\mathrm{CFB} \\
\text { carton, }\left(\mathrm{P}_{3}\right)-\mathrm{LDPE}\left(150 \text { gauge) liner }+ \text { CFB carton } ; \text { marigold flower extract: } \mathrm{T}_{1}-10 \%, \mathrm{~T}_{2}-15 \%, \mathrm{~T}_{3}-20 \% ; \text { neem oil: }\right. \\
\mathrm{T}_{4}-1 \%, \mathrm{~T}_{5}-1.5 \%, \mathrm{~T}_{6}-2 \%, \mathrm{~T}_{7} \text { - control. Means with same letters were not significantly different within each column } \\
(\mathrm{p}=0.05), \mathrm{n}=3\end{array}$} \\
\hline
\end{tabular}

\section{Pectin content}

The pectin content, in general, declined in all treatments. However, the pre-cooled fruits resulted in a higher pectin content $(1.2 \%)$ at the end of storage in both seasons, whereas, the $2 \%$ neem oil treatment $\left(\mathrm{T}_{6}\right)$ along with shrink-wrapped tray packing retained the maximum pectin content (1.7\%) with respect to pre-cooling in year 2006 and 2007 (Table 6). The fruits which were treated with marigold flower extracts (10-20\%) retained the lowest pectin content range from $0.9-1.2 \%$ at the end of 150 days of storage.

The decrease in pectin content in all treatments at the end of storage might be the result of pectolytic enzymes activity on natural pectin in the fruits (Nara et al., 2001). According to present findings, neem oil exhibited better retention of polygalacturonase (PG) activity over different concentrations of marigold flower extracts. The pre-cooling treatment and packaging materials also showed a marked effect on reduction of fruit softening during storage. Similar findings have been reported with regard to effect of plant extracts in retention of enzyme activity of fruits during storage (Kleeberg, 1996; Gakhukar, 1996; Singh et al., 2000).

\section{Fruit spoilage}

Spoilage of fruits due to rotting during storage was substantially reduced by pre-cooling and coating treatments. The $2 \%$ neem oil combined with pre-cooling was found to be the most effective in reducing spoilage while fruits in the control treatment exhibited the maximum spoilage (Table 7). The fruit spoilage percentage was lower, when fruits were stored at low temperature conditions, as the temperature at which a commodity is stored has a direct influence on its spoilage due to rotting. Spoilage causing organisms also find it difficult to establish and grow at low temperature. Gakhukar (1996) suggested that botanical extracts have the capability to act as anti-feedent and anti-repellent and thereby inhibiting the pathogenicity of various organisms. 
Table 6. Effect of pre-cooling, fruit coating and packaging on the pectin content and polygalacturonase (PG) activity of Royal delicious apples during storage at $2 \pm 1^{\circ} \mathrm{C}$ for 150 days

\begin{tabular}{|c|c|c|c|c|c|c|c|c|c|c|c|c|}
\hline \multicolumn{13}{|c|}{ Pectin content (as \% calcium pectate) } \\
\hline \multicolumn{2}{|c|}{ Treatments } & \multicolumn{5}{|c|}{2006} & \multicolumn{6}{|c|}{2007} \\
\hline & & \multicolumn{2}{|c|}{$\mathrm{C}_{1}$} & \multicolumn{3}{|c|}{$\mathbf{C}_{2}$} & \multicolumn{3}{|c|}{$\mathrm{C}_{1}$} & \multicolumn{3}{|c|}{$\mathbf{C}_{2}$} \\
\hline $\mathbf{P}$ & $\mathbf{P}_{1}$ & $\mathbf{P}_{2}$ & $\mathbf{P}_{3}$ & $\mathbf{P}_{1}$ & $\mathbf{P}_{2}$ & $\mathbf{P}_{3}$ & $\mathbf{P}_{1}$ & $\mathbf{P}_{2}$ & $\mathbf{P}_{3}$ & $\mathbf{P}_{1}$ & $\mathbf{P}_{2}$ & $\mathbf{P}_{3}$ \\
\hline$\overline{\mathrm{T}_{1}}$ & $1.0^{\mathrm{b}}$ & $0.9^{\mathrm{a}}$ & $0.9^{\mathrm{a}}$ & $1.0^{\mathrm{b}}$ & $0.9^{\mathrm{b}}$ & $0.9^{\mathrm{b}}$ & $1.0^{\mathrm{b}}$ & $0.9^{\mathrm{a}}$ & $0.9^{\mathrm{a}}$ & $0.9^{\mathrm{b}}$ & $0.9^{\mathrm{b}}$ & $0.9^{\mathrm{b}}$ \\
\hline $\mathrm{T}_{2}$ & $1.1^{\mathrm{c}}$ & $1.1^{\mathrm{b}}$ & $1.1^{\mathrm{b}}$ & $1.1^{\mathrm{c}}$ & $1.0^{\mathrm{c}}$ & $1.1^{\mathrm{c}}$ & $1.1^{\mathrm{c}}$ & $1.1^{\mathrm{b}}$ & $1.1^{\mathrm{b}}$ & $1.1^{\mathrm{c}}$ & $1.0^{\mathrm{c}}$ & $1.1^{\mathrm{c}}$ \\
\hline $\mathrm{T}_{3}$ & $1.2^{\mathrm{d}}$ & $1.1^{\mathrm{b}}$ & $1.2^{\mathrm{c}}$ & $1.2^{\mathrm{d}}$ & $1.0^{\mathrm{c}}$ & $1.1^{\mathrm{c}}$ & $1.2^{\mathrm{d}}$ & $1.1^{\mathrm{b}}$ & $1.1^{\mathrm{b}}$ & $1.1 \mathrm{c}$ & $1.0^{\mathrm{c}}$ & $1.1^{\mathrm{c}}$ \\
\hline $\mathrm{T}_{4}$ & $1.3^{\mathrm{e}}$ & $1.2^{\mathrm{c}}$ & $1.3^{\mathrm{d}}$ & $1.3^{\mathrm{e}}$ & $1.2^{\mathrm{d}}$ & $1.2^{\mathrm{d}}$ & $1.3^{\mathrm{c}}$ & $1.2^{\mathrm{c}}$ & $1.2^{\mathrm{c}}$ & $1.3^{\mathrm{d}}$ & $1.1^{\mathrm{d}}$ & $1.2^{\mathrm{d}}$ \\
\hline $\mathrm{T}_{5}$ & $1.6^{\mathrm{f}}$ & $1.5^{\mathrm{d}}$ & $1.5^{\mathrm{e}}$ & $1.6^{\mathrm{f}}$ & $1.4^{\mathrm{e}}$ & $1.5^{\mathrm{e}}$ & $1.5^{\mathrm{d}}$ & $1.4^{\mathrm{d}}$ & $1.5^{\mathrm{d}}$ & $1.5^{\mathrm{e}}$ & $1.4^{\mathrm{e}}$ & $1.5^{\mathrm{e}}$ \\
\hline $\mathrm{T}_{6}$ & $1.7^{\mathrm{g}}$ & $1.6^{\mathrm{e}}$ & $1.7^{\mathrm{f}}$ & $1.7^{\mathrm{g}}$ & $1.6^{\mathrm{f}}$ & $1.7^{\mathrm{f}}$ & $1.7^{\mathrm{e}}$ & $1.6^{\mathrm{e}}$ & $1.7^{\mathrm{e}}$ & $1.7^{\mathrm{f}}$ & $1.6^{\mathrm{f}}$ & $1.6^{\mathrm{f}}$ \\
\hline $\mathrm{T}_{7}$ & $0.9^{\mathrm{a}}$ & $0.9^{\mathrm{a}}$ & $0.9^{\mathrm{a}}$ & $0.7 \mathrm{a}$ & $0.6^{\mathrm{a}}$ & $0.7^{\mathrm{a}}$ & $0.9^{\mathrm{a}}$ & $0.9^{\mathrm{a}}$ & $0.9^{\mathrm{a}}$ & $0.6^{\mathrm{a}}$ & $0.6^{\mathrm{a}}$ & $0.6^{\mathrm{a}}$ \\
\hline Mean & 1.2 & & & 1.2 & & & 1.2 & & & 1.1 & & \\
\hline $\begin{array}{l}\text { Initial va } \\
\mathrm{CD}_{0.05} \mathrm{C}\end{array}$ & 0.01 & $\begin{array}{l}1.98 \\
\mathrm{xPxT}=\end{array}$ & & & & $\begin{array}{l}1.90 \\
\mathrm{C}=\end{array}$ & & & & & & \\
\hline
\end{tabular}

\section{Polygalacturonase (PG) activity (\% loss in viscosity of substrate)}

\begin{tabular}{|c|c|c|c|c|c|c|c|c|c|c|c|c|}
\hline $\mathrm{T}_{1}$ & $15.7^{\mathrm{e}}$ & $15.2^{\mathrm{a}}$ & $15.7^{\mathrm{d}}$ & $15.1^{\mathrm{c}}$ & $15.2^{\mathrm{a}}$ & $15.7^{\mathrm{e}}$ & $15.7^{\mathrm{d}}$ & $15.2^{\mathrm{a}}$ & $15.8^{\mathrm{e}}$ & $15.5^{\mathrm{c}}$ & $15.2^{\mathrm{a}}$ & $15.8^{\mathrm{f}}$ \\
\hline $\mathrm{T}_{2}$ & $15.2^{\mathrm{c}}$ & $15.7^{\mathrm{c}}$ & $15.9^{\mathrm{e}}$ & $14.9^{\mathrm{b}}$ & $15.9^{\mathrm{c}}$ & $15.9^{\mathrm{g}}$ & $15.2^{\mathrm{c}}$ & $15.7^{\mathrm{d}}$ & $15.8^{\mathrm{e}}$ & $15.1^{\mathrm{b}}$ & $15.8^{\mathrm{c}}$ & $15.7^{\mathrm{e}}$ \\
\hline $\mathrm{T}_{3}$ & $15.7^{\mathrm{f}}$ & $16.1^{\mathrm{f}}$ & $15.5^{\mathrm{c}}$ & $15.6^{\mathrm{e}}$ & $16.2^{\mathrm{e}}$ & $15.5^{\mathrm{d}}$ & $15.7^{\mathrm{d}}$ & $15.8^{\mathrm{e}}$ & $15.4^{\mathrm{d}}$ & $15.6^{\mathrm{d}}$ & $15.8^{\mathrm{c}}$ & $15.4^{\mathrm{d}}$ \\
\hline $\mathrm{T}_{4}$ & $15.1^{\mathrm{d}}$ & $15.5^{\mathrm{b}}$ & $15.7^{\mathrm{d}}$ & $15.2^{\mathrm{d}}$ & $15.5^{\mathrm{b}}$ & $15.8^{\mathrm{f}}$ & $15.8^{\mathrm{e}}$ & $15.4^{\mathrm{b}}$ & $15.8^{\mathrm{e}}$ & $15.8^{\mathrm{e}}$ & $15.5^{\mathrm{b}}$ & $15.7^{\mathrm{e}}$ \\
\hline $\mathrm{T}_{5}$ & $14.5^{\mathrm{a}}$ & $16.0^{\mathrm{e}}$ & $15.3^{\mathrm{b}}$ & $14.4^{\mathrm{a}}$ & $16.1^{\mathrm{d}}$ & $15.4^{\mathrm{c}}$ & $14.5^{\mathrm{a}}$ & $16.0^{\mathrm{f}}$ & $15.3^{\mathrm{c}}$ & $14.4^{\mathrm{a}}$ & $16.1^{\mathrm{d}}$ & $15.3^{\mathrm{c}}$ \\
\hline $\mathrm{T}_{6}$ & $15.0^{\mathrm{b}}$ & $15.8^{\mathrm{d}}$ & $14.9^{\mathrm{a}}$ & $15.1^{\mathrm{c}}$ & $15.9^{c}$ & $14.9^{\mathrm{a}}$ & $15.0^{\mathrm{b}}$ & $15.8^{\mathrm{e}}$ & $14.9^{\mathrm{a}}$ & $15.1^{\mathrm{b}}$ & $15.8^{\mathrm{c}}$ & $14.9^{\mathrm{b}}$ \\
\hline $\mathrm{T}_{7}$ & $15.7^{\mathrm{e}}$ & $15.5^{\mathrm{b}}$ & $15.3^{\mathrm{b}}$ & $15.9^{\mathrm{f}}$ & $15.5^{\mathrm{b}}$ & $15.0^{\mathrm{b}}$ & $15.8^{\mathrm{e}}$ & $15.5^{\mathrm{c}}$ & $15.2^{\mathrm{b}}$ & $15.8^{\mathrm{e}}$ & $15.5^{\mathrm{b}}$ & $14.8^{\mathrm{a}}$ \\
\hline \multicolumn{4}{|c|}{ C15.5 } & 15.5 & & & 15.5 & & & 15.4 & & \\
\hline \multicolumn{4}{|c|}{10.04} & & & & & & & & & \\
\hline
\end{tabular}

Note: $\mathrm{C}_{1}$ - pre-cooled; $\mathrm{C}_{2}$ - without pre-cooled; $\left(\mathrm{P}_{1}\right)$ - shrink-wrapped tray packing, $\left(\mathrm{P}_{2}\right)$ - Paper mould tray $+\mathrm{CFB}$ carton, $\left(\mathrm{P}_{3}\right)$ - LDPE (150 gauge) liner + CFB carton; marigold flower extract: $\mathrm{T}_{1}-10 \%, \mathrm{~T}_{2}-15 \%, \mathrm{~T}_{3}-20 \%$; neem oil: $\mathrm{T}_{4}-1 \%, \mathrm{~T}_{5}-1.5 \%, \mathrm{~T}_{6}-2 \%, \mathrm{~T}_{7}$ - control. Means with same letters were not significantly different within each column $(\mathrm{p}=0.05), \mathrm{n}=3$

Table 7. Effect of pre-cooling, fruit coating and packaging on the fruit spoilage (\%) of Royal delicious apples during storage at $2 \pm 1^{\circ} \mathrm{C}$ for 150 days

\begin{tabular}{|c|c|c|c|c|c|c|c|c|c|c|c|c|}
\hline \multicolumn{2}{|c|}{ Treatments } & \multicolumn{5}{|c|}{2006} & \multicolumn{6}{|c|}{2007} \\
\hline & & & & & C & & & C & & & $C_{2}$ & \\
\hline $\mathbf{P}$ & $\mathbf{P}_{1}$ & $\mathbf{P}_{2}$ & $\mathbf{P}_{3}$ & $\mathbf{P}_{1}$ & $\mathbf{P}_{2}$ & $\mathbf{P}_{3}$ & $\mathbf{P}_{1}$ & $\mathbf{P}_{2}$ & $\mathbf{P}_{3}$ & $\mathbf{P}_{1}$ & $\mathbf{P}_{2}$ & $\mathbf{P}_{3}$ \\
\hline$\overline{\mathrm{T}_{1}}$ & $0.1^{\mathrm{b}}$ & $0.2^{\mathrm{c}}$ & $0.1^{\mathrm{b}}$ & $0.1^{\mathrm{b}}$ & $0.2^{\mathrm{c}}$ & $0.1^{\mathrm{b}}$ & $0.1^{\mathrm{b}}$ & $0.1^{\mathrm{b}}$ & $0.1^{\mathrm{b}}$ & $0.1^{\mathrm{b}}$ & $0.1^{\mathrm{b}}$ & $0.2^{\mathrm{c}}$ \\
\hline $\mathrm{T}_{2}$ & $0.0^{\mathrm{a}}$ & $0.2^{\mathrm{c}}$ & $0.2^{\mathrm{c}}$ & $0.1^{\mathrm{b}}$ & $0.2^{\mathrm{c}}$ & $0.2^{\mathrm{c}}$ & $0.0^{\mathrm{a}}$ & $0.2^{\mathrm{c}}$ & $0.2^{\mathrm{c}}$ & $0.1^{\mathrm{b}}$ & $0.2^{\mathrm{c}}$ & $0.2^{\mathrm{c}}$ \\
\hline $\mathrm{T}_{3}$ & $0.1^{b}$ & $0.1^{b}$ & $0.1^{\mathrm{b}}$ & $0.1^{\mathrm{b}}$ & $0.1^{\mathrm{b}}$ & $0.1^{b}$ & $0.1^{\mathrm{b}}$ & $0.1^{\mathrm{b}}$ & $0.1^{b}$ & $0.1^{\mathrm{b}}$ & $0.1^{\mathrm{b}}$ & $0.1^{\mathrm{b}}$ \\
\hline $\mathrm{T}_{4}$ & $0.0^{\mathrm{a}}$ & $0.0^{\mathrm{a}}$ & $0.1^{\mathrm{b}}$ & $0.0^{\mathrm{a}}$ & $0.0^{\mathrm{a}}$ & $0.1^{b}$ & $0.0^{\mathrm{a}}$ & $0.0^{\mathrm{a}}$ & $0.1^{b}$ & $0.0^{\mathrm{a}}$ & $0.0^{\mathrm{a}}$ & $0.1^{\mathrm{b}}$ \\
\hline $\mathrm{T}_{5}$ & $0.0^{\mathrm{a}}$ & $0.1^{b}$ & $0.0^{\mathrm{a}}$ & $0.0^{\mathrm{a}}$ & $0.1^{\mathrm{b}}$ & $0.0^{\mathrm{a}}$ & $0.0^{\mathrm{a}}$ & $0.1^{\mathrm{b}}$ & $0.0^{\mathrm{a}}$ & $0.0^{\mathrm{a}}$ & $0.1^{\mathrm{b}}$ & $0.0^{\mathrm{a}}$ \\
\hline $\mathrm{T}_{6}$ & $0.0^{\mathrm{a}}$ & $0.0^{\mathrm{a}}$ & $0.0^{\mathrm{a}}$ & $0.0^{\mathrm{a}}$ & $0.0^{\mathrm{a}}$ & $0.0^{\mathrm{a}}$ & $0.0^{\mathrm{a}}$ & $0.0^{\mathrm{a}}$ & $0.1^{b}$ & $0.0^{\mathrm{a}}$ & $0.1^{\mathrm{b}}$ & $0.1^{\mathrm{b}}$ \\
\hline $\mathrm{T}_{7}$ & $0.3^{\mathrm{c}}$ & $0.8^{\mathrm{d}}$ & $0.3^{\mathrm{d}}$ & $0.3^{\mathrm{c}}$ & $0.8^{\mathrm{d}}$ & $0.3^{\mathrm{d}}$ & $0.3^{\mathrm{c}}$ & $0.8^{\mathrm{d}}$ & $0.3^{\mathrm{d}}$ & $0.3^{\mathrm{c}}$ & $0.1^{\mathrm{b}}$ & $0.3^{\mathrm{d}}$ \\
\hline Mean C & 0.1 & & & 0.1 & & & 0.1 & & & 0.2 & & \\
\hline
\end{tabular}

$\mathrm{CD}_{0.05} \mathrm{C}=0.002 \mathrm{CxPxT}=0.010$

Note: $\mathrm{C}_{1}$ - pre-cooled; $\mathrm{C}_{2}$ - without pre-cooled; $\left(\mathrm{P}_{1}\right)$ - shrink-wrapped tray packing, $\left(\mathrm{P}_{2}\right)$ - Paper mould tray $+\mathrm{CFB}$ carton, $\left(\mathrm{P}_{3}\right)$ - LDPE (150 gauge) liner + CFB carton; marigold flower extract: $\mathrm{T}_{1}-10 \%, \mathrm{~T}_{2}-15 \%, \mathrm{~T}_{3}-20 \%$; neem oil: $\mathrm{T}_{4}-1 \%, \mathrm{~T}_{5}-1.5 \%, \mathrm{~T}_{6}-2 \%, \mathrm{~T}_{7}$ - control. Means with same letters were not significantly different within each column $(\mathrm{p}=0.05), \mathrm{n}=3$ 


\section{CONCLUSIONS}

The results revealed that $1.5-2 \%$ concentration of neem oil as a surface coating along with pre-cooling at $10{ }^{\circ} \mathrm{C}$ was the most effective in providing a better physico-chemical umbrella, significantly lowering the fruit spoilage. The neem oil surface coating along with shrinkwrapped tray packing at $2{ }^{\circ} \mathrm{C}(85-90 \% \mathrm{RH})$ resulted in the longest storage life up to 150 days. Among the rates tested, the highest retention of fruit firmness, and pectin content, anthocyanin pigments, and polygalacturonase enzyme activity in fruits was recorded by $20 \%$ marigold extract, surface coated with shrink-wrapped tray packing along with pre-cooling. There were no seasonal differences observed on the quality of fruit storage between the year 2006 and 2007.

\section{ACKNOWLEDGEMENT}

Authors gratefully acknowledge the Sri Lankan Council for Agricultural Research Policy (CARP), Institute of Post Harvest Technology (IPHT) of Sri Lanka, and the Indian Council for Agricultural Research (ICAR) for their sponsorship in this study.

\section{REFERENCES}

Anon (2005). Apple. www.Fas.usda.gov/htp/horticulture/apples (accessed November 2007).

Anzueto, C.R. and Rizvi, S.S. (1985). Individual packaging of apples for shelf life extension. J. Food Sci. 50(2): 897-900.

Bhardwaj, R.L. and Sen, N.Z. (2003). Zero energy cool chamber storage of Mandarin (Citrus reticulate cv. Nagpur Santra). J. Food Sci. Technol. 40(6): 669-672.

Chadha, K.L. and Awasthi, R.P. (2005). The Apple. P. 408. In: Chadha, K.L. and Awasthi, R.P. (Ed.). Improvement, production and postharvest management, Malhorta Publishing House, New Delhi, India.

Deshmukh, P.B., Chavan, S.R. and Rehapurkar, D.M. (1992). A study of insecticidal activity of twenty indigenous plants. Pesticides 16(12): 7-10.

Gakhukar, R.T. (1996). Commercial and industrial aspects of neem based pesticide. Pestology 22(10): 15-32.

Horwitz W. (1980) Official Method of Analysis, 13th (Edn). Association of Analytical Chemists, Washington, D.C.

Kader, A.A., Zagory, D. and Kerbel, E.L. (1989). Modified atmosphere packaging of fruits and vegetables. CRC Crit. Rev. Food Sci. Nutri. 28: 1-30.

Kaynas, K. and Sivritepe, H.O. (1995). Effect of pre-cooling treatments on storage quality of mature green tomatoes. Acta Hort. 412: 200-209. 
Kleeberg, H. (1996). The Neem Azal conception: Future possibilities of the use of neem in biological and integrated pest management. pp. 875-882. In: Singh, R.P., Chavi, M. S., Raheja, R.K. (Ed). Neem and Environment, Oxford and IBH publication Company Pvt. Ltd., New Delhi.

Lurie, S.K. and Ben, A.R. (1990). Physiological changes in diphenyl treated 'Granny Smith' apples. Israel J. Bot. 38(34): 199-207.

Mahadevan, A. and Sridhar, R. (1982). Methods in Physiological Plant Pathology. Sivakami Publishers, Madras. pp. 28-30.

Nara, K., Kato, Y. and Motomura, Y. (2001). Involvement of terminal arabinose and galactose pectic compounds in mealiness of apple fruit during storage. Postharvest Biol. and Technol. 22(2): 141-150.

Ranganna, S. (1986). Hand Book of Analysis and Quality Control of Fruit and Vegetable Products.2nd (Edn). Tata McGraw Hill Pub. Co, New Delhi, pp. 12-99.

Ryall, A.L. and Uota, M. (1955). Effect of sealed polyethylene box liners on the storage life of Watsonville Yellow Newtown Apples. Proc. of Ameri. Soci. of Horti. Sci. 65: 203-210.

Singh Dinesh, D., Thakur, R.K. and Singh, D. (2003). Effect of pre-harvest sprays of fungicides and calcium nitrate on postharvest of Kinnw in low temperature storage. Plant disease Res. 18(1): 9-11.

Singh, J.N., Acharya, P. and Singh, B.B. (2000). Effect of $\mathrm{GA}_{3}$ and plant extracts on storage behaviour of mango (Mangifera indica) cv. Langra. Haryana J. Hort. Sci. 29:3-4.

Singh, K. and Chauhan, K.S. (1986). Effect of certain postharvest treatments on storage life of cv. 'L-49' guava. Haryana J. Hort. Sci. 11(3-4): 164-167.

Sonkar, R.K. and Ladaniya, M.S. (1999). Individual film wrapping of Nagpur mandarin with heat stretching film for refrigerated storage. J. Food Sci. Technol. 36: 273-276. 